\title{
Música e identidade na Romaria ao Divino Pai Eterno de Trindade, Goiás
}

\author{
José Reinaldo Felipe Martins Filho (Pontifícia Universidade Católica de Goiás, Goiânia, Goiás, Brasil) \\ jreinaldomartins@gmail.com
}

\begin{abstract}
Resumo: Este artigo discute o papel da música como constituinte identitário na Romaria ao Divino Pai Eterno desenvolvida no município de Trindade, em Goiás. Integra o horizonte mais amplo de nossas pesquisas sobre o catolicismo popular goiano em sua expressão musical - com resultados que envolvem não apenas a devoção ao Divino Pai Eterno, mas também outras manifestações da cultura religiosa goiana. Em primeiro lugar, verifica a presença da música mormente por meio do canto e da prática instrumental - nos primeiros anos da festa, beneficiando-se, para isso, das crônicas registradas pela Província Redentorista em Goiás, datadas de 1908 a 1963. Por conseguinte, vale-se do testemunho oferecido pelos romeiros entrevistados nos dias de festa, bem como dos princípios da análise retórica - com fundamentos não apenas culturais, mas teológicos -, elencando o que denominamos como o ranking dos principais exemplos musicais presentes na atualidade da devoção. Pretende contribuir nas discussões sobre culturas e religiosidades populares em Goiás, particularmente quando estas tocam temas como identidade, festas, religião e música. Palavras-chave: Música; Identidade; Romaria ao Divino Pai Eterno; Trindade-Goiás.
\end{abstract}

Music and Identity in Romaria to the Divine Eternal Father of Trindade, Goiás

Abstract: This article discusses the role of music as an identity constituent in the Pilgrimage to the Divine Eternal Father developed in the municipality of Trindade, in Goiás (Brazil). It integrates the broader horizon of our research on popular Catholicism in Goiás in its musical expression - with results that do not involve only devotion to the Divine Eternal Father, but also other manifestations of the religious culture of Goiás. First of all, it verifies the presence of the music - mainly through singing and instrumental practice - in the first years of the festival, benefiting from the chronicles recorded by the Redemptorist Province in Goiás, dating from 1908 to 1963. Consequently, is was based on the testimony offered by the pilgrims interviewed on feast days, as well as un the principles of rhetorical analysis - not only cultural but theological foundations - listing what we call the ranking of the main musical examples present in the actuality of devotion. It intends to contribute to the discussions about popular cultures and religiosities in Goiás, particularly when they touch themes such as identity, parties, religion and music. Keywords: Music; Identity; Pilgrimage to the Divine Eternal Father; Trindade/Goiás (Brazil).

\section{Palavras iniciais}

Restringindo nossas análises sobre o catolicismo popular em Goiás, ${ }^{1}$ neste artigo nos voltamos à Romaria ao Divino Pai Eterno de Trindade, Goiás, ${ }^{2}$ que, embora se trate de uma devoção estendida desde a metade do século XIX, somente a partir das últimas décadas ganhou projeção em cenário nacional, constituindo-se como o movimento religioso goiano com maior repercussão fora de nossas fronteiras geográficas. ${ }^{3}$ Adentraremos o universo musical desta festividade goiana com o intuito de realçar o que a música já representou e o que hoje ainda representa na manutenção da devoção. Como fontes primordiais para a construção deste texto estarão alguns arquivos da Província Redentorista em Goiás, partituras e depoimentos colhidos junto aos entrevistados nos dias da festa, bem como outras pesquisas que também versam sobre o Divino Pai Eterno. ${ }^{4}$ Além disso, sempre que necessário também serão indicadas outras referências como sugestão para o aprofundamento de aspectos menos relevantes para nosso estudo especificamente.

Em primeiro lugar, é preciso advertir que no contexto específico da devoção ao Pai Eterno a música não pode ser tomada isoladamente, senão em sua constante referência aos demais aspectos da identidade: é música de romaria, é música do devoto agradecido, é música que fala, simultaneamente, sobre e com o Divino Pai Eterno, é música como meio de propagação da crença. Isso porque, conforme destacou o seminarista Eurípedes Júnior, entrevistado por nossa pesquisa, 
[...] a música compõe significado à Romaria no sentido que desperta no povo uma identificação. Carrega traços do sentido originário e tradicional desta festa sendo bastante marcada pela piedade popular, pelo louvor ao Deus Pai Criador, pela relação do povo simples e sertanejo que procura sentido em Deus e por isso eleva seus louvores e clamores [...] (Eurípedes Júnior, 21 anos, estudante universitário).

As páginas que seguem, portanto, encarregam-se de dar ênfase ao lugar da música na composição identitária do movimento religioso representado pela romaria goiana.

\section{Canto e música no passado da festa}

Ao nos propormos investigar o lugar da música e do canto nas primeiras décadas da devoção ao Divino Pai Eterno, deparamo-nos com o empecilho de nos remetermos a um passado já longínquo e com escassa fonte documental, especialmente quando tomamos em conta a inexistência de um acervo musical específico da festa. Este, aliás, parece ser um costume recorrente em outras paróquias do interior goiano: não possuir um acervo especificamente dedicado à música. No caso de Trindade, contudo, uma hipótese pode ser levantada: em geral, os primeiros anos da festa eram "animados" por bandas de música contratadas de outras localidades (Pirenópolis, São José do Tocantins, Jaraguá, Nerópolis, entre outras). Nesse sentido, embora possuidores de considerável formação musical, tanto os padres redentoristas alemães, os primeiros a chegarem a Trindade com o intuito de reestruturar a festa, quanto as irmãs franciscanas posteriormente vindas a Campininhas das Flores, também com o propósito de cooperar na missão evangelizadora e catequética dos missionários, não dispunham da "matéria-prima” local necessária para a constituição de bandas e/ou corais à altura do que julgavam ser a qualidade necessária para o serviço litúrgico. Diante disso, notadamente, como melhor solução de um ponto de vista do custo benefício esteve a contratação de "músicos profissionais", conforme era praxe na grande maioria das paróquias goianas no século XIX e ainda em parte do século XX. Raros são, neste período, os testemunhos de corais autóctones unicamente voltados para a demanda de suas respectivas comunidades.

Em vista do que acabamos de justificar, torna-se praticamente impossível estabelecermos o perfil do repertório utilizado no período que perfaz desde o início da festa - passando pelo primado dos leigos na gerência dos festejos - até a primeira metade da década de 1960 (quando a influência do Concílio Vaticano II marcaria o surgimento de um novo contexto). Tal impedimento, contudo, não significa uma total impossibilidade de, por outro lado, aferirmos a presença da música na devoção. Isso porque, além dos testemunhos colhidos dos próprios devotos, também pudemos nos valer de outra importante fonte documental: as já mencionadas Crônicas dos padres redentoristas. Apesar de não se tratar de um documento de teor eminentemente musical, tais manuscritos representam o dia a dia da vida dos religiosos à frente das comunidades de Barro Preto e Campininhas das Flores. É nesse sentido que, entre relatos atinentes à administração paroquial, à economia, aos costumes do povo, à dinâmica interna da fraternidade religiosa, também descobrimos inúmeras menções ao elemento musical e sua integração ao contexto da devoção, particularmente como "embelezador" das liturgias e motivador de uma espiritualidade de comunhão e participação. Graças à indicação e partilha do professor Ângelo de Oliveira Dias, ${ }^{5}$ da Universidade Federal de Goiás, pudemos nos beneficiar deste material, gentilmente cedido a ele pelo missionário redentorista Pe. Clóvis Bovo. Trata-se, a princípio, de uma coletânea de crônicas registradas de 1908 a 1963 e utilizadas no processo de canonização do Venerável Pe. Pelágio Sauter ao qual voltaremos a nos referir adiante. Levando em conta que os missionários chegaram a 
Campininhas em 1894, a partir destas Crônicas tornar-se-á possível perscrutarmos o maior ou menor impacto da música sobre a composição da identidade religiosa que se desenvolveu em Barro Preto e, posteriormente, em Trindade.

Antes de tudo, chamou-nos a atenção a descrição oferecida por Pe. Wiggermann, citado por Jacób (2010), ao primeiro contato dos missionários alemães com a comunidade de Campininhas das Flores. Isso por conta de um elemento que para nós não pode ser desprezado. Como se não bastasse a longa viagem a cavalo, "molhados até os ossos entraram na Vila”. O cansaço e o frio, porém, não os impediram de estabelecer o ponto de partida da nova missão, instaurada no dia de Nossa Senhora de Guadalupe (12 de dezembro), a padroeira da América. Antes do banho ou do descanso, a pequena igreja do vilarejo impôs-se como o porto seguro do qual careciam. Foi nela que, "repletos de gratidão a Deus e Nossa Senhora, cantamos o Te Deum” (WIGGERMANN, Ano? apud JACÓB, 2010, p. 156 - grifo nosso). Não por acaso, pois, chamamos atenção para este momento originário na relação entre os missionários e a devoção - da qual seriam os guardiões dali em diante. Curiosamente, o primeiro ponto de intersecção entre a fé dos estrangeiros recém-chegados e a religiosidade do povo local foi o canto. Uma repetição da mesma iniciativa empreendida pela família de Constantino Xavier, ${ }^{6}$ quando reunida pela primeira vez ao redor do medalhão com a efígie da Santíssima Trindade: "diante dessa medalha costumava reunir a família para rezar o terço e cantar” (SANTOS, 1976, p. 54). Por um lado isto reforça o argumento antropológico de que a linguagem musical é o que há de mais radicalmente humano, ao ponto de a música ser apontada como o protótipo da "linguagem racional", apenas ulteriormente desenvolvida - já que na música se conjugam o "racional” e o "afetivo", não sobrepostos, mas equivalentes. ${ }^{7}$ Por outro lado, faz-nos reconhecer o traço direcional de uma religiosidade que viria a encontrar no canto e na música uma especial maneira de perpetuar-se: em primeiro lugar, como instrumento coletivo de oração e, por conseguinte, como ferramenta de comunicação e de difusão da crença.

Estando, porém, à luz da investigação obtida através das Crônicas redentoristas, outro fator igualmente chamou-nos a atenção, como segue: a presença de música instrumental e não apenas do canto, de maneira especial nos momentos mais importantes da devoção, como, por exemplo, nos dias da novena ao Pai Eterno. Isso é atestado em um dos relatos referentes à festa de 1908, conforme descrição do cronista, que também faz questão de realçar o esforço dos padres pela implementação do que julgavam ser a "boa música", estimulada junto aos festejos:

Naturalmente, a igreja torna-se pequena, não entrando nem a quinta parte. A igreja esteve sempre repleta nas missas e nas rezas, quando sempre se pregava. Nos três últimos dias, os romeiros enchiam a igreja por duas vezes, rezando, cantando, enquanto ofereciam seus donativos e cumpriam suas promessas, colocando tudo no altar. A renda, contando tudo, foi de 14 contos. Os quatro padres estiveram sempre ocupados com missas, anotações, administração dos sacramentos, casamentos, enquanto os irmãos cumpriam seus deveres com zelo e esforço. Umas 500 comunhões. Não houve desordem, graças a boa cooperação da polícia. A banda de música de Jaraguá contribuiu muito para o brilho da festa. Todos saíram contentes prometendo voltar com mais gente no próximo ano. Voltando de Trindade, vieram logo três carros de Goiabeiras buscar o altar e móveis da sacristia de lá. Foi trabalho de três meses do Ir. Simão (Crônicas, s.d, grifos nossos).

Note-se com especial atenção o que nomeamos como o "poder" da música de atrair, congregar, incentivar o retorno, fatores sempre explorados pela religião em sua ação ritualística. Em primeiro lugar, a oração que se manifesta como canto. Canto e música não apa- 
recem, portanto, como elementos periféricos da festa, mas, ao contrário, como integrantes imprescindíveis de seu corpus ritual, isto é, como o lócus, o lugar-tempo privilegiado para o transcurso do rito: durante o canto se faz os donativos, presta-se a devoção, o beijo à imagem, a procissão, o louvor ao Pai Eterno. Igualmente, a música deixa sua marca no fiel, ao ponto de que ao ser perguntado sobre que elemento melhor lhe traz a recordação de sua devoção e dos dias da festa, sem hesitar afirme: a música (englobando aqui especialmente o canto) - o caso de Eurípedes Júnior, como descreve: "sempre que me lembro da Romaria do Divino Pai Eterno ouço esta música [Somos povo de Deus caminhando] em minha mente com a imagem de uma procissão". Outros tantos exemplos são evocados pelo cronista, ao ponto de não ser possível neste trabalho elencar um a um. Expomos, contudo, alguns outros fragmentos a fim de dar legitimidade ao que sustentamos, como esta narrativa relativa à festa de 1914:

[...] No dia seguinte, domingo e festa do nome de Maria, missa in pontificalibus, com entrada solene: com cruz, bandeiras, música e grande povo. Fez uma comovente prática sobre Nossa Senhora (Crônicas, s.d, grifo do autor).

Ou o que lemos na descrição de 1917:

[...] Passaram por aqui, os salesianos padres Malan, Carlos Peretto, João Bálsola e Luiz, com 22 bororós; trabalhando na catequese dos índios em Mato Grosso. A fim de interessar as altas autoridades e angariar auxílio, enviaram a tocar música a rapazes de 9 a 18 anos. Padre Malan foi com eles a exposição nacional do Rio, onde se exibiram na abertura, com grande admiração de todos. Eram batizados, não porém crismados. O bispo de Goiás os crismou a 8 de dezembro, sendo padrinhos altas autoridades a começar pelo presidente. Ficaram aqui, por 3 dias; fizeram música dentro e fora da igreja (Crônicas, s.d, grifos nossos).

Frente ao exposto, poderíamos nos perguntar: por que a insistência do cronista em realçar que houve música "dentro e fora da igreja"? Seria, acaso, uma redundância meramente ocasional? Segundo nos parece, não! Ao contrário, trata-se de um recurso retórico que pretende ilustrar o alcance festivo do evento. Isso porque, noutras palavras, festa boa é aquela que não cabe dentro da "bitola" e extrapola. ${ }^{8} \mathrm{O}$ fato de ter havido música dentro e fora da igreja retrata que a festividade litúrgica seguiu-se à festa do povo, com comida, bebida e, possivelmente, alguma dança (mesmo que não propriamente nas dependências do santuário). A festa do povo tornava-se, então, manifestação dita em música, em dança, em comida. Daí não estarmos falando simplesmente da música como integrante da identidade religiosa, mas da identidade da festa de maneira geral. ${ }^{9}$ Diz o cronista: "[enquanto] a banda de música se alternava com os cânticos. Muitos disseram: 'É a festa mais bonita do ano!”’ (Crônicas, s.d).

Maiores detalhes sobre os usos e costumes relativos à música na festa ao Pai Eterno também são oferecidos pelo cronista, especialmente quando tratam: da tradição de missas cantadas e com pregação para os dias mais solenes, ${ }^{10}$ dos dias e celebrações em que a música não poderia faltar ${ }^{11}$ e, até mesmo, do valor cobrado pelos músicos e da ausência de maiores vínculos destes com a igreja - e, mesmo, com a religião. Sobre este último ponto, aliás, vale a pena lermos o seguinte relato que, segundo conseguimos verificar, refere-se à festa de 1910:

[...] Papel importante tem [a] música, que cobra de $300 \$$ a $1.000 \$$. Músicos, que nunca põem o pé na igreja, sopram nos instrumentos, até quase perderem o fôlego. Nos dias da novena, após uma melodia não litúrgica, como uma valsa, tocam os três pa- 
dre-nossos, ave-marias e Glória Patri, mas tão forte, que as vozes são abafadas (Crônicas, s.d).

Fato é que enquanto os músicos continuaram sendo apenas contratados para os dias de festa, problemas desta ordem foram seguramente recorrentes. Isso porque perícia instrumental e conhecimento litúrgico são, ainda hoje, conteúdos nem sempre conjugados. Daí a necessidade do estabelecimento de conjuntos oriundos da própria comunidade, especialmente após o Concílio Vaticano $\mathrm{II}^{12}$ e o incentivo dado ao primado das assembleias no canto. De algum modo, isso certamente contribuiu para que a qualidade musical das festas também regredisse, já que nunca antes se havia procurado cultivar iniciativas formativas ao redor da música instrumental e do canto, tais como a organização de corais. Aliás, com o passar das décadas a presença de música instrumental, bem como de grupos corais a quatro vozes, tornou-se praticamente inexistente junto à festa do Pai Eterno - com exceção para algumas iniciativas da última década. Assim, no dilema entre qualidade performática/ sonora e participação popular, os anos posteriores a 1960 privilegiaram o segundo item, em detrimento do primeiro. Isso ao ponto de a atual identidade musical da Romaria ser constituída unicamente de peças para o canto, escritas em uníssono e sem acompanhamento instrumental notado em partitura. Também reside aí outro motivo para a ausência de materiais musicais (partituras, livretos de canto) referentes às primeiras décadas da romaria, já que este tema, embora fundamental para a constituição da identidade da devoção, nunca fora objeto de atenção por parte dos dirigentes eclesiásticos - especialmente após 1960.

\section{Canto e música na atual Romaria}

Não obstante, os desafios no tocante a uma maior compreensão acerca da musicalidade dos primórdios da devoção, voltando aos nossos dias, canto e música continuam a exercer um papel significativo tanto como reforço da identidade da Romaria quanto como reelaboração do seu perfil identitário. A fim de mensurarmos este alcance, ao longo das entrevistas procuramos construir uma espécie de ranking dos cantos mais mencionados pelos devotos como imediatamente relacionados com a devoção ao Pai Eterno. Curiosamente, chegamos a uma lista dos cinco mais recorrentes. A princípio julgávamos encontrar um elenco bem mais amplo, propósito frustrado pela constatação do pequeno número obtido. Por um lado, este resultado confirma o que intuímos acerca da composição das identidades. Em tempo de fluidez nas relações e nas instituições a noção de identidade também é submetida a certa relativização, o que supõe uma construção dinâmica, constantemente impelida ao jogo da negociação e da hibridez (CANCLINI, 2011; ORTIZ, 1987). Há, então, elementos que se hibridizam, dando lugar a novas composições. Outros, contudo, que não estão disponíveis à negociação, permanecem por mais algum tempo, causando a impressão de continuidade, marcando também o espaço para a tradição. Daí que apesar de possuir um extenso repertório, que se renova a cada ano, a atual conjuntura da festa ao Divino Pai Eterno, segundo a apreciação de seus devotos, manifesta-se de maneira especial através de cinco peças musicais que têm permanecido nas últimas décadas - e, dentre estas, nenhuma unicamente instrumental - quais sejam, ordenadas pelo título: Romaria, Somos povo de Deus, Ó Trindade, vos louvamos, Ave-Maria do Padre Pelágio e Nós pedimos, ó Pai Eterno. ${ }^{13}$ Os parágrafos que seguem tentam elucidar elementos de significação de cada um destes cantos através da análise de conteúdo e, notadamente, levando em conta o sentido aferido pelos devotos consultados. Embora faça referência à melodia dos cantos, nossa análise privilegiará sua estrutura textual, mencionando-a sempre que julgar oportuno. 
Entre os cantos mais marcantes da festa, acompanhando os devotos desde sua partida rumo a Trindade e os encorajando a sempre novamente se porem a caminho rumo ao "templo sagrado em forma de cruz", devemos nos remeter à tradicional Romaria - que, aliás, traz como título sua fidelidade a esta modalidade de expressão do catolicismo popular. De acordo com nossa pesquisa, Romaria está entre os cinco principais cantos apontados como resposta para a pergunta sobre a identidade da festa ao Divino Pai Eterno. É o canto da chegada a Trindade, quando, ao longe, pode-se avistar a Basílica consagrada à devoção à Santíssima Trindade. É o canto dos que se achegam, movidos pelo desejo de tornarem-se próximos do objeto de sua devoção. Basta nos aproximar dos inúmeros ônibus, advindos de diversas partes do país, para logo ouvirmos o estribilho: "Sou romeiro que caminha, sou devoto do Senhor, caminhando pra Terra Santa, velha Trindade da fé e do amor". E parece ser este, de fato, o sentimento que também motivou o cantor e instrumentista Walter José quando da composição deste hino. De lá para cá este se tornaria o refrão dos romeiros, afinal esta é a definição por excelência do devoto do Pai Eterno: romeiro, caminhante rumo a sua Terra Prometida.

Por um lado, o canto se estrutura levando em conta o passo a passo da preparação para a Romaria. Descreve o forte vínculo entre a vida do campo e a devoção, tendo como protagonista a figura do carro de bois, já mencionado por este capítulo e com profunda influência sobre o reconhecimento da identidade religiosa da Romaria. Por outro lado, enquanto sintetiza o itinerário do devoto - carreiro e romeiro - o texto também revela a profundidade da relação estabelecida entre o romeiro e o lugar em que este pode expressar a sua fé: a "Terra Santa coberta de luz". Isto nos ajuda a realçar o aspecto ao mesmo tempo territorial e tradicional da identidade religiosa, neste caso não apenas mantida ou reforçada, mas sugerida a todos quantos se deparam com sua expressão na forma de canto:

Levantei cedo, juntei a boiada, a fé no peito e o pé no chão.

Meu velho carro cantou na estrada e o pó vermelho levantou no chão. Num passo lento saiu na jornada pra romaria da devoção.

\section{Refrão:}

Sou romeiro que caminha, sou devoto do Senhor! Caminhando pra Terra Santa, velha Trindade da fé e do amor!

Pra ir na terra do Pai Eterno minha jornada durou longos dias, trabalhei duro o ano inteiro, fiz os meus planos pra romaria. Pedi os anjos pra iluminar os meus passos e o Pai Eterno pra ser o meu guia

Ao ver ao longe seu santuário, Templo Sagrado em forma de cruz, aonde o Pai fez a sua morada com Santo Espírito e seu Filho Jesus. Dou meus louvores por chegar de novo na Terra Santa coberta de luz. 


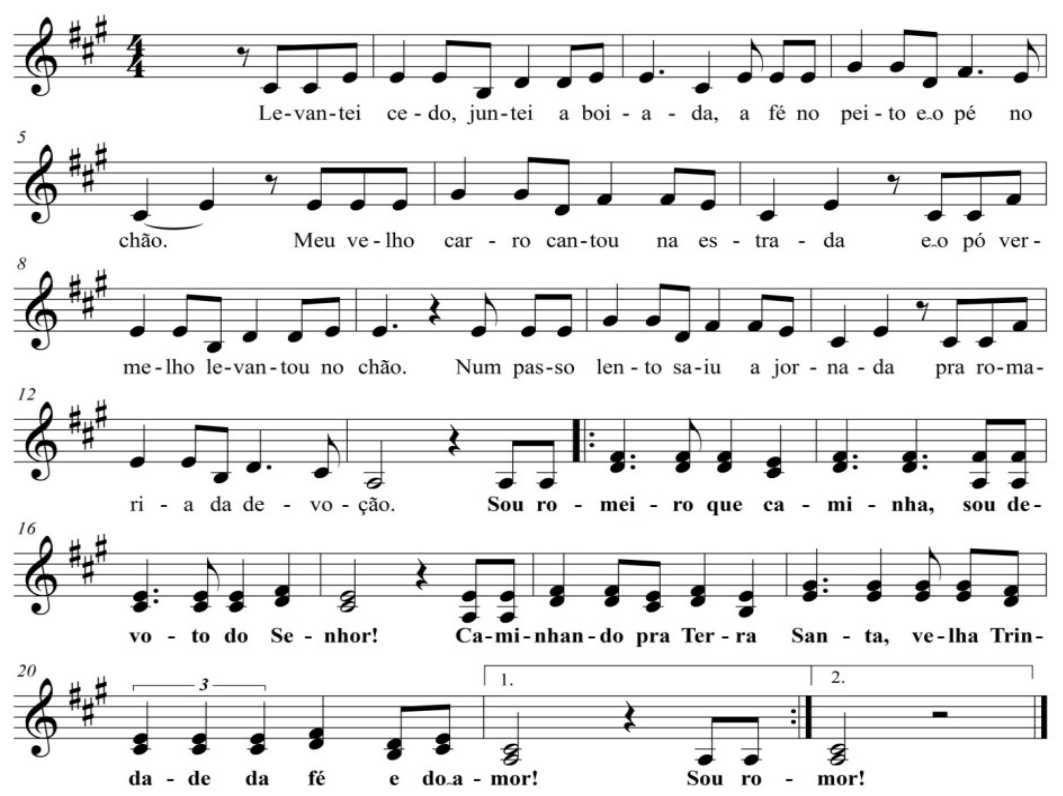

Exemplo musical 01: Romaria ao Divino Pai Eterno. Composição de Valter José.

Fonte: Transcrição nossa, 2018.

Como vimos, apesar de o aspecto devocional da romaria ficar evidenciado no canto acima descrito, o que denominamos como o atual "hinário identitário" da festa ao Pai Eterno não está limitado a este aspecto da devoção - isto é, a romaria em sentido estrito. Ao longo das décadas alguns outros cantos passaram a integrar o conjunto simbólico da festa, entre os quais merece destaque o canto de abertura utilizado durante todos os dias de novena, a saber: Somos povo de Deus caminhando. Embora o aspecto do povo em marcha, não apenas em alusão ao movimento das romarias rumo a Trindade, mas também à própria concepção de Igreja como "povo a caminho", instaurada desde os primeiros influxos do Concílio Vaticano II, este canto também se dedica a traduzir numa linguagem mais popular fortes elementos da teologia trinitária conservada pela tradição da Igreja Católica desde o período da Patrística (que corresponde aos seis primeiros séculos do cristianismo). Para o jovem Ítalo Pereira Rodrigues, ouvido por nós, “a letra dessa música fala da realidade do romeiro, da sua vivência, que espera o ano todo para ir à casa do Pai e agradecer as graças alcançadas. A letra mesmo fala tudo, na minha analise".

Assim, apesar de sua autoria e origem ser de difícil mensurabilidade, estamos diante de um canto estruturado sob a forma de hino - isto é, com estrofes conseguintes, sem a interposição de um refrão. Arriscando-nos a uma análise de conteúdo das estrofes, em primeiro lugar vale a pena destacarmos a evolução gradual empreendida desde a apresentação da figura da Santíssima Trindade, passando pela sua afirmação como Pai, Filho e Espírito, pela coroação da Virgem Maria e chegando à vivência da fé, como compromisso assumido por referência ao Deus-comunhão. Num jogo de palavras, a primeira estrofe sugere uma dupla interpretação que, vista sob uma perspectiva mais profunda, mostra-se complementar: o caminho para Trindade, terra da romaria, é transfigurado num itinerário rumo à Trindade Sagrada, de cujo movimento a primeira se torna protótipo. Neste percurso é o Espírito Santo quem guia o devoto à casa do Pai, que não caminha sozinho, mas amparado pelo Deus Filho, irmão. A voz que vem do céu com o forte imperativo - "caminhai!" - pertence ao que se manifesta "sem véus" com o propósito de, como afirma a terceira estrofe, tornar-se auxílio na passagem da cruz para a luz - entendendo por cruz o sofrimento cotidianamente enfrentado pelo devoto. A última estrofe, enfim, estabelece o elo entre fé e vida, de modo que 
o pôr-se a caminho do romeiro deve ser enxergado sob a ótica do testemunho. Vejamos como segue:

Somos povo de Deus caminhando para a luz da Trindade sem véu. Se a Trindade aqui vimos rezando, somos todos romeiros do céu. (bis)

Pelo Espírito Santo guiados demandamos à casa do Pai. Para nós, em Deus Filho irmanados, uma voz vem do céu: caminhai! (bis)

Tendo a Virgem coroada na glória junto a Deus, no seu trono de luz, compreendemos que a nossa vitória é conquista de amor pela cruz. (bis)

Nossa fé, testemunho profundo, alimenta-se em graça e oração. Consagrar para Deus este mundo há de ser nosso anseio cristão. (bis)

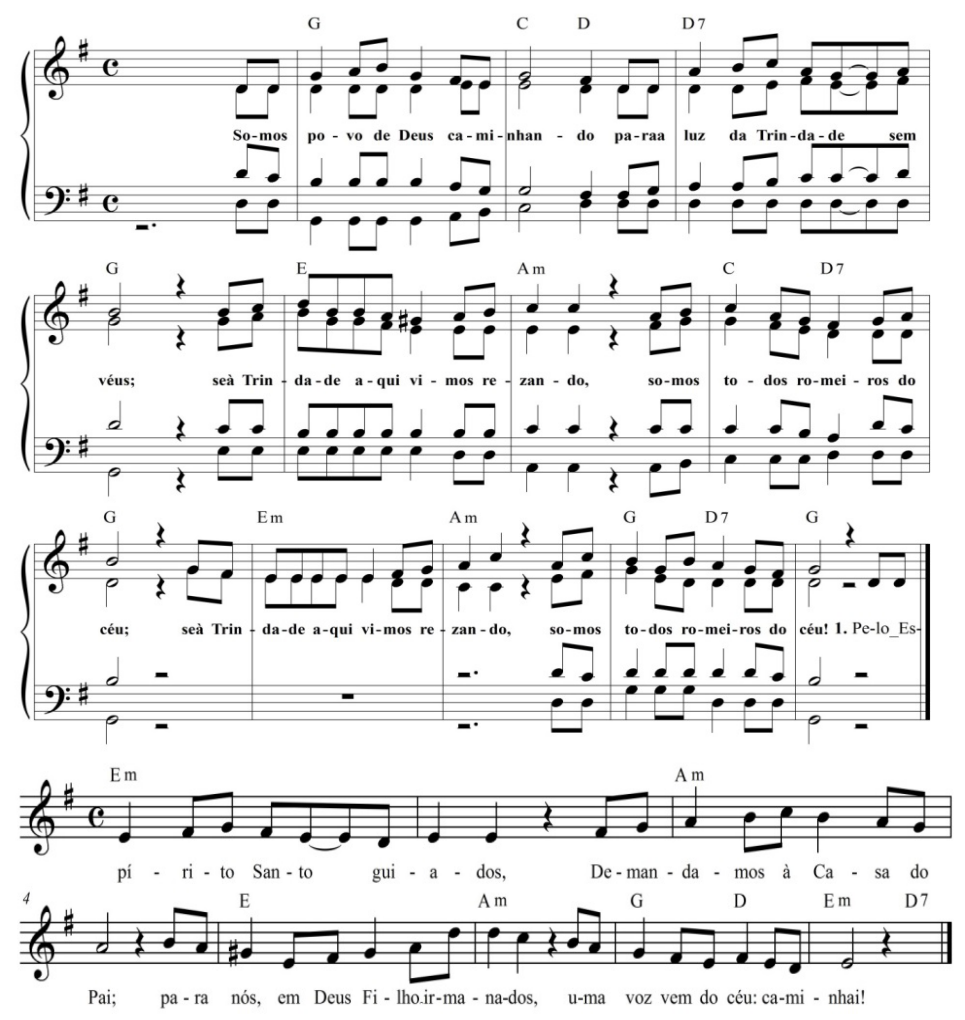

Exemplo musical 02: Somos Povo de Deus caminhando.

Fonte: Transcrição e arranjo nossos, 2018.

Como temos defendido, indo muito além da linguagem simplesmente representativa da razão, a música alcança o núcleo de significação dos devotos, sendo capaz de transmitir a mais fina teologia por meio de seu efeito de catarse, de configuração, de repetição. Trata-se de um fenômeno ainda melhor compreendido no contexto dos ritos religiosos, que oportunizam o lócus espaço-temporal essencial para que este objetivo seja efetivamente alcançado (OTTO, 1985; ELIADE, 1992). No contexto do rito, dada a sua constância e repetição, ideologias também são introjetadas, contribuindo de maneira ativa na elaboração de 
um "perfil" identitário. Assim, se, por um lado, consideramos eficaz o uso da música na transmissão de conteúdos de ordem teológica, o mesmo se aplica em se tratando de outras ideologias atinentes ao perfil ideológico da devoção, como é o caso de outro canto mencionado pelos entrevistados como um dos cinco principais expoentes musicais da Romaria do Pai Eterno, a saber: Ó Trindade, vos louvamos. Originalmente composto para a Campanha da Fraternidade (CF) de 1989, promovida pela Conferência Nacional dos Bispos do Brasil, com o tema "Comunicação para a verdade e a paz", este canto se refere ao aspecto comunitário da Santíssima Trindade, como modelo para o exercício de uma autêntica comunicação. Deixando de lado, contudo, seu uso para referir-se à temática comunicacional propriamente dita, tornou-se frequente nas celebrações do Domingo da Santíssima Trindade, que marca a retomada do Tempo Comum após o período litúrgico da Páscoa. Por analogia, acabou sendo inserido no repertório da festa ao Divino Pai Eterno, consolidando-se atualmente como um dos principais expoentes de sua identidade religiosa musical.

Sua forma simples, interposta por um refrão, atua como facilitadora na participação por parte das grandes assembleias reunidas para os dias da festa. Ao contrário da referência anterior, contudo, este canto apresenta um maior acento às questões ideológicas que, notadamente, fazem ressaltar a dimensão política da Romaria - senão do cristianismo que esta representa. Fiel a sua proposta originária, o tema da comunicação permanece como mote para o louvor à Santíssima Trindade. Outros temas, no entanto, vão sendo pouco a pouco realçados pelas estrofes, tendo como núcleo a dimensão comunitária do cristianismo - a exemplo da crença em um Deus-comunidade: Pai-Filho-Espírito - que, por isso, deve estender sua ação ao mundo de maneira geral, empenhando-se pela transformação das estruturas sociais e de dominação, sobretudo dos mais pobres. A menção ao contexto de segregação econômica, por exemplo, está claramente demonstrada na primeira estrofe, a qual interpõe a "palavra do viver" como antídoto contra a "tentação da ganância e do poder". O mesmo ocorre nas demais estrofes que chamam a atenção, respectivamente, para a transformação social, a conversão do mundo por meio da ação de Deus que fala na história, a restauração da comunhão entre toda humanidade, a semeadura da esperança e do perdão, entre outros temas. Em geral, temos aqui um forte exemplo de como a música pode contribuir para realçar o papel da religião como elemento de insurgência e transformação social. A identidade religiosa, reforçada pela cultura musical, isto é, pela conservação de um repertório, passa, assim, pelo dado da ação política/pública, não se restringindo nem a uma interpretação de religião como uma construção alheia ao mundo concreto, nem, tampouco, de música como instrumento de alienação. Desse modo, é novamente possível constatar a atuação do fenômeno musical como agente estruturante da dinâmica social dos grupos, na medida em que se torna interface de comunicação entre o humano e o divino, bem como entre os humanos uns com os outros. ${ }^{14}$ Vejamos a poesia completa a seguir:

Refrão:

Ó Trindade, vos louvamos,

vos louvamos pela vossa comunhão.

Que esta mesa favoreça, favoreça nossa comunicação.

Contra toda a tentação da ganância e do poder, nossas bocas gritam juntas a palavra do viver. A palavra do viver.

Na montanha com Jesus no encontro com o Pai, recebemos a mensagem: ide ao mundo e o transformai. Ide ao mundo e o transformai. 
Deus nos fala na história e nos chama à conversão: vamos ser palavras vivas proclamando a salvação. Proclamando a salvação.

Vamos juntos festejar cada volta de um irmão.

É o amor que nos acolhe, restaurando a comunhão.

Restaurando a comunhão.

Comunica quem transmite a verdade e a paz, quem semeia a esperança e o perdão que nos refaz. E o perdão que nos refaz.

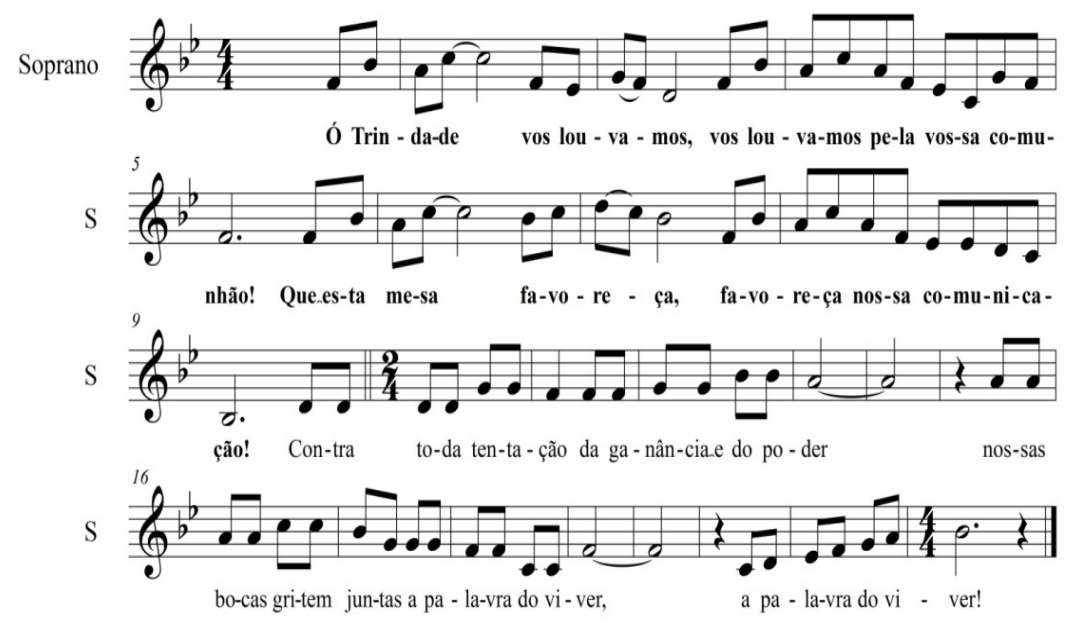

Exemplo musical 03: Ó Trindade, vos louvamos. Originalmente integrou o caderno de partituras da Campanha da Fraternidade (CF) de 1989.

Fonte: Edição nossa.

Há, ainda, outros dois cantos integrados à lista dos cinco mais mencionados como principais representantes da identidade sonora da atual Romaria ao Divino Pai Eterno. Entre estes chama-nos a atenção o único que não está diretamente ligado à devoção à Santíssima Trindade, nem à cidade de Trindade ou ao Divino Pai Eterno. Trata-se de uma Ave-Maria, cuja letra mantém-se fiel ao texto da tradição católica, embora envolta por uma melodia cuja autoria é atribuída ao Venerável Pe. Pelágio Sauter. ${ }^{15}$ Tendo dedicado a maior parte de sua vida a serviço das comunidades de Trindade e de Campinas, em Goiás, o falecido religioso encontra-se em processo de canonização junto a Santa Sé. Este, aliás, é um dos principais motivos da inserção de sua pretensa composição junto ao repertório da festa ao Pai Eterno. Após ter contribuído por tantos anos em prol da realização da mesma, o religioso com fama de santo também é um dos motivos de atração dos fiéis a Trindade. Atualmente existe até uma igreja construída em sua memória, em cuja estrutura encontra-se sepultado o seu corpo. A Ave-Maria do Padre Pelágio, como é conhecida pelos devotos, atua, portanto, como uma forte propaganda pela canonização do santo popular e, ao mesmo tempo, uma forma de os devotos expressarem sua devoção à Virgem Maria, originalmente pensada como tema central da imagem do Pai Eterno. A devoção a Nossa Senhora, aliás, deve ser considerada como relativa à devoção ao Pai Eterno, sobretudo por conta de sua presença na composição da imagem. O devoto do Divino Pai Eterno é, nesse sentido, devoto de Maria, a Mãe coroada. Tal ocorre especialmente porque olhando para a imagem reconhece em Maria a figura mais próxima, ${ }^{16}$ a humana que foi elevada à glória de Deus. Torna-se ela um protótipo, um modelo para o devoto que pretende transpor a distância da "cruz à luz". 


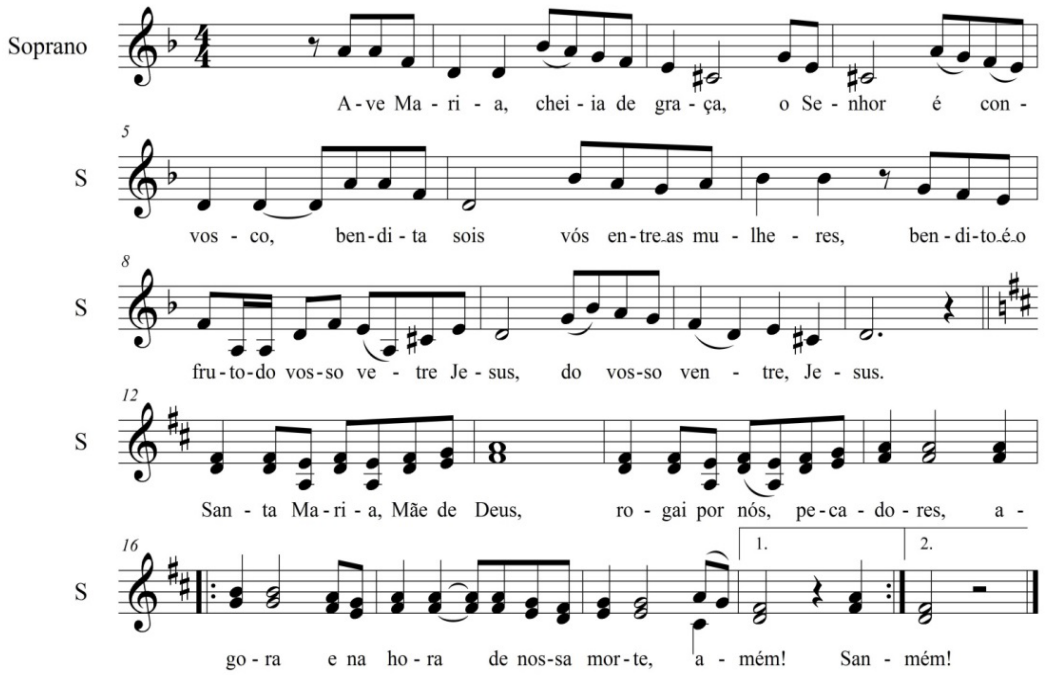

Exemplo musical 04: Ave-Maria do Padre Pelágio. Apesar de a origem da composição não poder ser precisada, em geral entre os devotos este canto é atribuído ao religioso Padre Pelágio Sauter, missionário redentorista alemão.

Fonte: Transcrição nossa, 2018.

A melodia, de estrutura relativamente simples e sóbria, oportuniza a participação de todos no canto. Na passagem da primeira parte da antífona para a sua resposta há modulação da tonalidade menor para maior. Após o advento da midiatização da devoção do Pai Eterno a melodia de Padre Pelágio tornou-se conhecida por devotos advindos de outras partes do país, ao ponto de fazer-se parte imprescindível do conjunto ritual que atualmente constitui a devoção ao Divino Pai Eterno de Trindade. Na novena é sempre entoada num momento particularmente dedicado à Virgem Maria. Na Celebração Eucarística aparece, em geral, após a comunhão.

Enfim, se no início desta seção nos referimos ao canto que pode ser considerado como ponto de partida no itinerário dos romeiros rumo à festa em Trindade, perpassando, igualmente, todos os dias de novena, também é preciso mencionarmos o que entendemos como a "oração de despedida" ao término de cada celebração. Referimo-nos à súplica de bênção, entoada após a comunhão em preparação para a solene bênção com a imagem do Divino Pai Eterno. Em se tratando da música religiosa, particularmente com relação aos contextos litúrgicos, tradicionalmente a música sempre atuou como elemento de estabelecimento e interrupção do tempo/espaço do sagrado, numa feliz referência a Mircea Eliade (1992). Há, então, o canto de começo, que marca o tempo e o espaço, conferindo a ambientação necessária para o desenvolvimento da liturgia. Por conseguinte, deve também haver o canto de término ou de saída (saideira), entoado após os ofícios sagrados, a fim de dissipar a assembleia congregada rumo ao cotidiano de suas vidas (o que a tradição protestante consolidou como o poslúdio). Pensando a festa ao Divino Pai Eterno não poderia ser diferente, de modo que há também um canto que, sempre que entoado, cumpre a tarefa de comunicar aos fiéis a conclusão de mais um rito. Desta vez a adaptação efetivada por Walter José a partir de um conhecido canto da Romaria de Bom Jesus da Lapa, na Bahia, ${ }^{17}$ destina-se a suplicar as bênçãos do Divino Pai Eterno, estendendo, aleatoriamente, o ponto focal de sua propagação às famílias, aos jovens, aos romeiros, às crianças, aos doentes e a quantas outras necessidades for pertinente. Envolto numa melodia festiva o canto é formado por refrão e estrofes, numa estrutura que pode facilmente ser transposta para outros textos:

Nós pedimos, ó Pai Eterno, a vossa bênção:

vossa bênção e proteção! 
É de todo o coração que vos pedimos: vossa bênção e proteção!

Para todos os romeiros vossa bênção, vossa bênção e proteção! (bis)

Para todas as famílias vossa bênção, vossa bênção e proteção! (bis)

$[\ldots]$
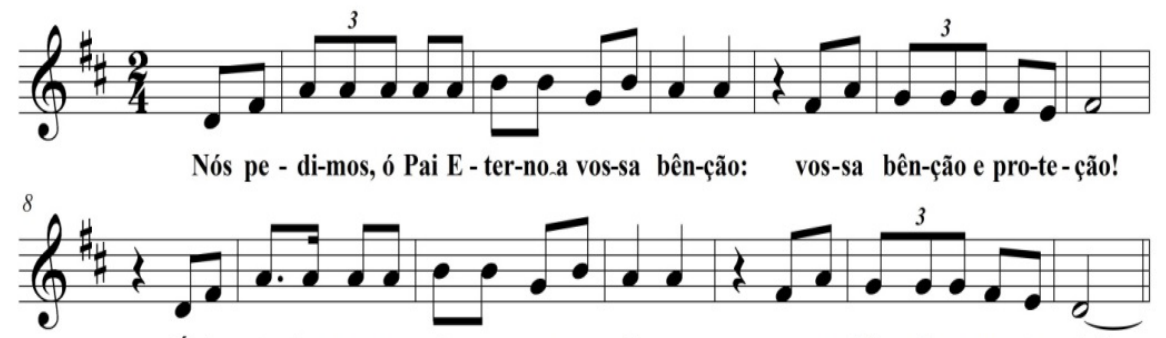

É de to-do.o co-ra - ção que vos pe - di-mos: vos-sa bên-ção e pro-te - ção!

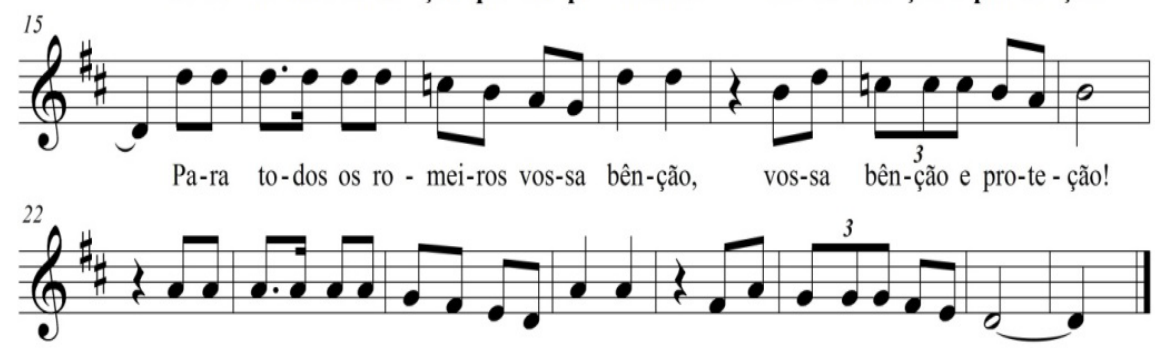

Pa-ra to-dos os ro-mei-ros vos-sa bên-ção, vos-sa bên-ção e pro-te- ção!

Exemplo musical 05: Nós pedimos, ó Pai eterno. Trata-se de uma adaptação do canto dos romeiros de Bom Jesus da Lapa, na Bahia.

Fonte: Transcrição nossa, 2018.

\section{Palavras finais}

É curioso como em meio a algumas dezenas de composições que se intercalam a cada ano nas várias celebrações que integram a Festa ao Divino Pai Eterno, conforme o relato dos devotos entrevistados, possamos destacar apenas este pequeno conjunto de cinco cantos como mais constantes. Em nenhum momento, por exemplo, houve qualquer menção a alguma peça unicamente instrumental - senão uma ou outra introdução, como o marcante ponteio da viola na introdução de Romaria ou o "toque de silêncio", executado às 5:30 da manhã durante a procissão da penitência. ${ }^{18}$ Isso nos ajuda a compreender que, de fato, a noção de identidade geralmente não implica considerarmos um extraordinário quantitativo de características. Em se tratando da identidade - e, neste caso, da identidade religiosa - a lei da qualidade sobrepõe-se sobre a da quantidade. Não se trata, por isso, de toda e qualquer referência ao que de algum modo é relativo à devoção. Importa o que a identifica para os membros de seu corpus fidei, seu conjunto de crenças e valores. Nas palavras dos devotos, a identidade diz respeito "àquilo que não pode faltar", "ao que ninguém abre mão", ao que é necessário para que "a festa seja a festa”. Isto, como vimos, não corresponde a um vasto conjunto estrutural, mas ao que se considera essencial - contexto em que a música novamente aparece como elemento de integração.

Em síntese, embora a atual Romaria ao Divino Pai Eterno se distinga em muitos aspectos do que era praticado nos primeiros anos da devoção, a partir do que pudemos obser- 
var e coletar nas entrevistas, a música constitui-se como um dos elementos de continuidade, estando presente desde os primeiros anos da festa e permanecendo, nos dias atuais, como indicativo na definição de sua identidade. Faz-se, desse modo, presente nos primórdios e na atualidade da devoção, motivando, trazendo recordações, consolando dores, partilhando alegrias, inspirando a transformação, propagando a crença, instituindo o rito, introjetando a teologia, potencializando o ser humano ao além de si, ao encontro com o sagrado e com os outros com os quais partilha a fé.

Em primeiro lugar, segundo nossa observação, a música comparece como expressão da fé, isto é, como linguagem da oração. Isso levando em conta sua capacidade de, por um lado, também traduzir o inaudito (assim como a imagem faz ver o invisível) e, por outro, de expressar o indizível. O mesmo é de algum modo salientado pelo catequista Márcio Alves, quando perguntado sobre o valor da música na devoção ao Pai Eterno: "religiosos fervorosos dizem que quem canta, reza duas vezes [...]. Não acredito nisso, mas acredito que a música pode contribuir para a alegria quando é para tal objetivo. Contudo, a música tem a missão de acalmar os corações, emocionar, motivar e alegrar”. Diante do sagrado, como nos ensinou Otto (1985), os sentidos se transformam: a percepção sensível esvanece-se em tremor e a palavra se emudece. O canto torna-se, então, meio privilegiado de expressão da crença, ultrapassando o domínio simplesmente dado de uma linguagem racionalizada. Daí que a presença da música na festa ao Pai Eterno manifeste-se eminentemente pelo canto. É palavra que se faz canto, animando a fé, estabelecendo o contato com a divindade, agradecendo o milagre, louvando pelas bem-aventuranças. Porquanto, ao falarmos da presença da música nessa forma de expressão do catolicismo popular goiano estaremos, antes de tudo, nos referindo à música entendida como canto (palavra cantada, oração dita em canto) - com raríssimas exceções e, ainda assim, apenas para a primeira metade do séc. XX.

Por conseguinte, em segundo lugar, a linguagem musical comparece como um dos principais elementos identificadores da festa - do caráter festivo da romaria, seja este considerado em termos religiosos ou, mesmo, como extensão da fé nas demais manifestações de alegria, sempre concomitantes ao ofício religioso stricto sensu. Notam-se tanto os vários testemunhos registrados pelo autor das Crônicas redentoristas quanto a palavra dos devotos entrevistados por nossa pesquisa. Em todo caso, "festa boa" é aquela em que há boa música; ao ponto de que uma festa sem música definitivamente não é uma festa, como declarou Francisco Netto à nossa pesquisa: "a música é um dos fatores que embalam a festa, não há como ter festa sem música, e, com certeza, a música é parte viva na identidade da festa”. A linguagem musical/sonora torna-se, então, o modo de expressão da festa - que também se traduz em dança, em comida e em bebida, na convivência de uns com os outros, como, de algum modo, sinalizamos no segundo capítulo deste estudo. Elevando o ser humano ao além de si, num processo de transcendência que também é próprio da religião, a música coopera na construção do aspecto extravagante da festa, isto é, que vai além da norma e a supera: o aspecto que extravasa.

Ainda conforme nossas observações, em terceiro lugar a linguagem musical se expressa como um dos elos de continuidade entre o passado e o presente da festa. Como pudemos observar, a música esteve presente no primeiro ato de devoção de Constantino Xavier, reunido com sua família ao redor da verônica com a efígie da Santíssima Trindade: foi, naquela ocasião, oração feita em canto. Compareceu, novamente, no primeiro contato dos missionários alemães quando de sua chegada a Campininhas das Flores - permanecendo, ainda, em seu apostolado junto aos devotos do Divino Pai Eterno nas décadas subsequentes. Canto e música deram o "tom" festivo das primeiras décadas de festa, embalando as procissões. Enfim, o canto continua como um dos principais instrumentos de identificação da ro- 
maria, evocado pelo devoto quando solicitado por um exemplo de sua fidelidade à devoção: "sou romeiro que caminha, sou devoto do Senhor [...]". Considerados como instrumentos de oração - coletiva (seja em meio aos tantos devotos reunidos na praça do Santuário Novo, seja no trajeto, à pé, pela Rodovia dos Romeiros - que liga Goiânia a Trindade) e individual (durante a veneração à imagem, no beijo à fita, na idiossincrasia de cada fiel em sua vigília, desde o primeiro raiar do sol até o seu ocaso) - a música, sobretudo através do canto, pode ser apontada como um dos principais "fios da meada" responsáveis por perscrutar e manter a unidade entre os vários momentos do processo de consolidação desta tradição. Consiste no povo - dimensão laical -, no canto da igreja - dimensão institucional - e permanece sendo o canto da fé, expressão limítrofe entre formal e informal, entre o oficial e o popular.

\section{Notas}

1 Este artigo está inserido no horizonte mais amplo de nossa pesquisa de doutoramento junto ao Programa de Pós-Graduação em Ciências da Religião da Pontifícia Universidade Católica de Goiás, sob orientação do Dr. Clóvis Ecco. Os dados mencionados se referem ao material colhido com autorização do Comitê de Ética em Pesquisa da PUC Goiás, com parecer consubstanciado sob número 62955116.9.0000.0037. Pesquisa subsidiada pela Fundação de Amparo à Pesquisa do Estado de Goiás (FAPEG) com bolsa de auxílio à pesquisa.

2 Conforme dados do Instituto Brasileiro de Geografia e Estatística (IBGE), Trindade é um município brasileiro do estado de Goiás, na região Centro-Oeste do país. Pertence à mesorregião do Centro Goiano e à microrregião de Goiânia, localizando-se a oeste da capital do Estado, a uma distância de cerca de $18 \mathrm{~km}$. Possui uma área de aproximadamente $719 \mathrm{~km}^{2}$, ocupando a $8^{\mathrm{a}}$ posição no quesito do município mais populoso de Goiás, com 119.385 habitantes, segundo estimativas de 2016. Surgiu do extinto município de Campinas que, em 1909, tinha como distrito Barro Preto. Após sua fragmentação, em 1920, muda-se de nome em homenagem à história dos agricultores Ana Rosa e Constantino Xavier, casal que encontrou o medalhão com a efígie do Divino Pai Eterno. A cidade, com temperatura média anual de $23,2^{\circ} \mathrm{C}$, possui vegetação de cerrado. Seu Índice de Desenvolvimento Humano (IDH) é de 0,699, considerando-se como médio em relação ao restante do país.

3 Inspirados pela devoção do Santuário de Trindade, construíram-se, ao longo das décadas, outros santuários pelo interior goiano, igualmente dedicados ao Divino Pai Eterno. Este é o caso de Cachoeira de Goiás, Panamá e Silvânia. Assim, trata-se de uma devoção significativa para caracterizar o catolicismo popular goiano não apenas por sua repercussão, mas pela abrangência territorial que adquiriu para os próprios goianos. Há, no entanto, notícias de uma devoção autônoma, também reconhecida sob o título de Divino Pai Eterno, na cidade de Tiradentes, Minas Gerais. Como relata Van Der Poel (2013, p. 331), “Tiradentes (MG) possui um santuário da Santíssima Trindade, construído entre 1810-1822. A imagem do Pai Eterno ostenta uma coroa parecida com a antiga tiara papal. No peito, traz o Divino Espírito Santo, e no meio do trono está Jesus Cristo, o Filho de Deus. Em maio ou junho é celebrado o jubileu (novena) da Santíssima Trindade que atrai muitos romeiros, vindos de perto e de longe, para agradecer e pagar promessas. Desde 1894 é administrado pelos redentoristas.” Esta mesma devoção, com imagem diferente da de Trindade, Goiás, também se repete nos municípios mineiros de Campina Verde e Guapê.

4 A esse respeito, além do material que utilizaremos em nossa discussão, há uma série de trabalhos dedicados à Romaria do Divino Pai Eterno de Trindade, tomada por diferentes enfoques, que podem facilmente ser localizados nas bases de dados das universidades do Centro-Oeste. Este é o caso de COELHO, O comércio varejista periódico na festa de Trindade, Go; TELLES, Um olhar geográfico e cultural sobre a festa do Divino Pai Eterno em Trindade, Go; GOMES, Festa religiosa, sujeito e imagem - além, notadamente, dos vários trabalhos, entre teses e dissertações, desenvolvidos junto ao Programa de Pós-Graduação em Ciências da Religião da PUC Goiás.

5 O professor Ângelo Dias também é autor da pesquisa O canto coral em Goiânia, em parceria com Germano Lopes. Trata-se de um aprofundamento nas questões atinentes à prática musical na capital goiana a partir das fontes musicológicas presentes nas Crônicas dos padres redentoristas em Goiás, entre 1908 e 1965. Ver DIAS, 2010.

6 Personagem a quem se atribui ter encontrado o primeiro medalhão com a efígie da Santíssima Trindade coroando Nossa Senhora. Representa o ponto de partida da devoção.

7 E isso confirma o forte apelo simbólico atribuído à linguagem musical, pois "somente ela pode expressar, justamente em virtude de seu caráter abstrato, as regiões mais profundas de nosso ser, a dinâmica de nossos sentimentos, nosso inconsciente, a harmonia universal, as verdades, etc” (FUBINI, 2001, p. 61, tradução nossa).

8 Nos termos de Souza (2008, p. 120), “'festar', como o verbo 'amar', na plenitude da sua natureza intransitiva requer tudo e requer nada. É necessidade que se tem e que se inventa. Necessidade de ser e não ser, de fazer e desfazer, de comprar e de perder, pois [...] o homem tem 'fome' de festa”.

9 Música como identidade de maneira geral.

10 Diz o cronista: "Nos últimos três, há música, tratada em qualquer cidade e missa cantada com pregação, cada dia; e à noite, reza solene com pregação e música. Quatro padres têm muito a fazer, mal achando tempo para comer" (Crônicas, s.d). 
11 Diz o cronista: "Nos últimos quatro dias vem a música, que tocando na reza e na missa dá um tom mais festivo às cerimônias. A polícia enviada pelo governo manteve a ordem; não houve nenhum caso” (Crônicas, s.d).

12 Evento mais significativo da Igreja Católica nos últimos séculos. Ocorrido na década de 1960.

13 Ao longo de nossa pesquisa outros dois cantos também foram mencionados pelos devotos, como segue: a Ladainha a Nossa Senhora e Vinde Santo Espírito. Em ambos os casos trata-se de uma tentativa de ampliar o foco da devoção para além da figura do Pai Eterno. Com origem e autoria desconhecida, a Ladainha à Virgem Maria pode acompanhar a festa desde os seus primeiros anos, o que reforça o caráter mariano do catolicismo popular expresso em Trindade, que, apesar de ter reconhecido a centralidade do Pai, jamais desprezou a forte referência à Maria, Mãe de Deus. O mesmo pode ser pensado no tocante ao canto de invocação ao Espírito Santo, já que as outras duas pessoas da Santíssima Trindade gozam de menor evidência nas celebrações - que sempre dão ênfase ao Pai (ao menos formalmente, já que o caráter híbrido da devoção sempre ofereceu espaço para a menção aos outros componentes da imagem: o Filho, o Espírito Santo e a Virgem Maria). Assim, a tradição popular julgou oportuna a inserção de um momento de invocação ao Espírito Santo no início das novenas, em que se consagrou a indicação do canto, entoado como rito.

14 O mesmo verificamos em nossa pesquisa de Mestrado em Música, cf. MARTINS FILHO, 2016.

15 Em termos musicológicos, nunca foi encontrada nenhuma prova de que esta Ave-Maria é mesmo de autoria de Pe. Pelágio. Entre as hipóteses mais aceitas, há aquela que segundo trata-se de uma versão europeia estimada pelo religioso e utilizada por ele a fim de propagar a oração em português da Ave-Maria junto aos devotos. Entre outros argumentos tal hipótese é reforçada pela semelhança silábica da melodia em questão em contraste com o texto latino. A consagração popular, no entanto, tornou inseparáveis esta versão e seu pretenso autor, Pe. Pelágio.

16 Costume no catolicismo santos domésticos.

17 Na Bahia cantam: "Nós pedimos, ó Bom Jesus, a vossa bênção, vossa bênção e proteção [...]”.

18 Em geral, trata-se do momento de maior participação por parte dos próprios moradores de Trindade.

\section{Referências}

CANCLINI, Nestor García. Culturas híbridas: estratégias para entrar e sair da modernidade. Tradução: Heloísa Pezza Cintrão, Ana Regina Lessa; tradução da introdução de Gênese Andrade. 4.ed. São Paulo: Editora da Universidade de São Paulo, 2011. (Ensaios Latino-americanos, 1).

COELHO, T. Dicionário crítico de política cultural. 3. ed. São Paulo: FAPESP/Iluminuras, 2004.

CRÔNICAS. Crônicas provinciais redentoristas (1908-1965). Goiânia, s/d. (manuscritos).

ECCO, Clóvis; MARTINS FILHO, José Reinaldo Felipe. Música é identidade! Elementos de (re) construção na Romaria ao Divino Pai Eterno. Paralellus (Online), v. 8, n. 19, p. 459-475, 2017.

ELIADE, Mircea. O sagrado e o profano. Tradução: Rogério Fernandes. São Paulo: Martins Fontes, 1992. (Tópicos).

FUBINI, Enrico. Música y lenguaje en la estetica contemporánea. Madrid: Alianza Editorial, 2001.

JACÓB, Amir Salomão. A Santíssima Trindade do Barro Preto: história da Romaria de Trindade. Trindade, GO: Redentorista, 2000.

MARTINS FILHO, José Reinaldo Felipe. Música Ritual e Inculturação: um estudo a partir da Folia de Reis de São José do Morumbi, GO. 2016. F?. Dissertação (Mestrado em qual área?) - Programa de Pós-Graduação em Música da UFG, Goiânia, 2016. [manuscrito]

ORTIZ, Fernando. Contrapuento cubano del tabaco y el azúcar. Caracas: Biblioteca Ayacucho, 1987.

OTTO, Rudolf. O Sagrado: um estudo do elemento não-racional na ideia do divino e a sua relação com o racional. Tradução de Prócoro Velasques Filho. São Bernardo do Campo, SP: Imprensa Metodista, 1985.

SANTOS, Miguel Archângelo Nogueira dos. Trindade de Goiás, uma cidade santuário: conjun- 
tura de um fenômeno religioso no Centro-Oeste brasileiro. 1976. Dissertação (Mestrado em História) - Universidade Federal de Goiás, Goiânia, 1976.

SOUZA, Ana Guiomar Rêgo. "Festando na ‘Pátria Formosa do Índio Goyá”. In. Paixões em cena: a Semana Santa na cidade de Goiás (século IXX). Brasília: UNB/ Instituto de Ciências Humanas - Departamento de História, 2008. [manuscrito - tese de doutorado] p. 120-172.

VAN DER POEL, Franciscus Henricus. A origem do congado. Disponível em: < http://www.religiosidadepopular.uai vip.com.br/congadorigem.htm>. Acesso em: 29 jul. 2014.

José Reinaldo Felipe Martins Filho é doutorando em Ciências da Religião pela Pontifícia Universidade Católica de Goiás, na linha de pesquisa Cultura e Sistemas Simbólicos. Mestre em Música (2016) e em Filosofia (2014), ambos pela Universidade Federal de Goiás. Tem graduação em Filosofia, Teologia e e Música. Participa de grupos de pesquisa vinculados a diferentes IES do Brasil. 